\title{
BODY CONDITION SCORE AND SEASON OF CALVING EFFECTS ON PHYSIOLOGICAL PARAMETERS, PRODUCTIVE AND REPRODUCTIVE PERFORMANCE OF FRIESIAN COWS
}

\author{
M. Atieha ${ }^{1 *}$ and M. Abdelsalam ${ }^{1,2}$ \\ 1- College of Agriculture and Veterinary Medicine, Qassim University, Al-Qassim 51452, Saudi Arabia, 2- \\ Department of Animal Production, Faculty of Agriculture, Alexandria University, El-Shatby, Alexandria \\ 21545, Egypt, "Corresponding author: Mohamed Atieha, e-mail: mohamed0_9@yahoo.com
}

Received: $26 / 8 / 2019$

Accepted: 15/10/2019

\section{SUMMARY}

Physical body condition of cows reared under tropical and subtropical conditions had an effect on productive and reproductive traits. The reproduction efficiency is considered an important factor affecting the production and economic efficiency of dairy cows. The present study was designed to investigate the effect of dam body condition score and season of calving on productive and reproductive performance of dairy cattle under hot condition. Data were collected from thirty Friesian cows raised at the experimental Farm, College of Agriculture and Veterinary Medicine, Qassim University through 2013-2015 in summer and winter seasons. The body condition score (BCS) was recorded on scale 1 to 5 . Cows were weighed at calving and body activity was determined. Physiological parameters (Rectal temperature, Respiration rate and Pulse rate) were measured. The traits studied represent total milk yield, daily milk yield, first estrus after calving, calving to conception interval (days open), number of services per conception, estrus rate, pregnancy rate. Two way analysis of variance was used with BCS and season of calving as fixed effect.

The results showed that the physiological parameters increased in hot season. The cows with BCS of 3 to 4 can decrease their physiological parameters. Cows calved in hot season have lower weights, milk yield and body activity. Cows with BCS of 3 showed the highest movement and the heaviest amount of milk yield. Low reproductive performance was found for cows calved in summer season. It could be concluded that Friesian cows in tropics and subtropics had an ability to survive and adjusted their body to withstand high ambient temperature. Body condition score is considered an important factor to reflect ability of Friesian cows raised in hot environments.

Keywords: Physiological parameters, Body condition score, milk yield, body activity, Reproductive performance

\section{INTRODUCTION}

Food and water security will be one of the other priorities for humankind in the $21^{\text {st }}$ century, therefore the demand of milk and meat from animal will increase in the next decades. High environment temperatures may compromise reproductive efficiency of farm animals and hence negatively affect productivity of milk and meat. Reproduction efficiency is a major factor affecting the production and economic efficiency of dairy cows. Many reports showed that heat stress is the major environmental factor responsible for lower fertility in dairy cows during the summer months in hot areas of the world (Roth et al., 2000 and Rensis \& Scaramuzzi, 2003). Ghosh et al. (2017) pointed out that the heat stress reduced milk production and body weight of dairy cows. Rensis et al. (2002) reported that heat stress reduces conception rate during the hot season. The efficiency of follicular selection and dominance are also altered during heat stress, with adverse effects on the quality of ovarian follicles (Badinga et al., 1993). The milk yield of dairy cows reared under temperate condition was higher than those of tropical and subtropical countries (Usman et al., 2013). The present work was carried out to study the effect of season and body condition score on productive and reproductive performance of dairy cattle.

\section{MATERIALS AND METHODS}

\section{Animals and management:}

The present study was carried out on thirty Friesian cows in third lactation through 2013-2015 (ten cows calved during Dec., 2013 and Jan 2014, fifteen cows were calved during August 2014 and five cows were calved during Dec., 2014 and Jan 2015). Dairy cows raised at the experimental Farm, College of Agriculture and Veterinary Medicine, Qassim University. Artificial insemination is main activity of the farm. The cows were artificially inseminated mated 45 days to two months after calving. The heifers were mated when they reach weight of $320-350 \mathrm{~kg}$. The procedures of the experiment were carried out according to the principles and regulations of the Ethics Committee, Qassim University. The cows were housed in open housing with propellers fitted with water sprays. Machine milking was performed for lactating cows twice daily at 6.0 a.m. and 16.0 p.m. Drying off of the cows is practiced when the production drops to 25 liter of milk per day and practiced two months before calving. Animals were fed ad libitum available berseem (medicago sativa) or $3 \mathrm{~kg}$ alfalfa hay and 3 $\mathrm{kg}$ commercial concentrate mixture besides $2 \mathrm{~kg}$ barely. The chemical composition ( $\%$ DM) of 
commercial concentrate mixture was tabulated in table 1 . Water was offered to animals at all day times.
Salt bricks were available at pen with free access. All animals were healthy.

Table 1. Chemical composition (\% DM) of commercial concentrate mixture.

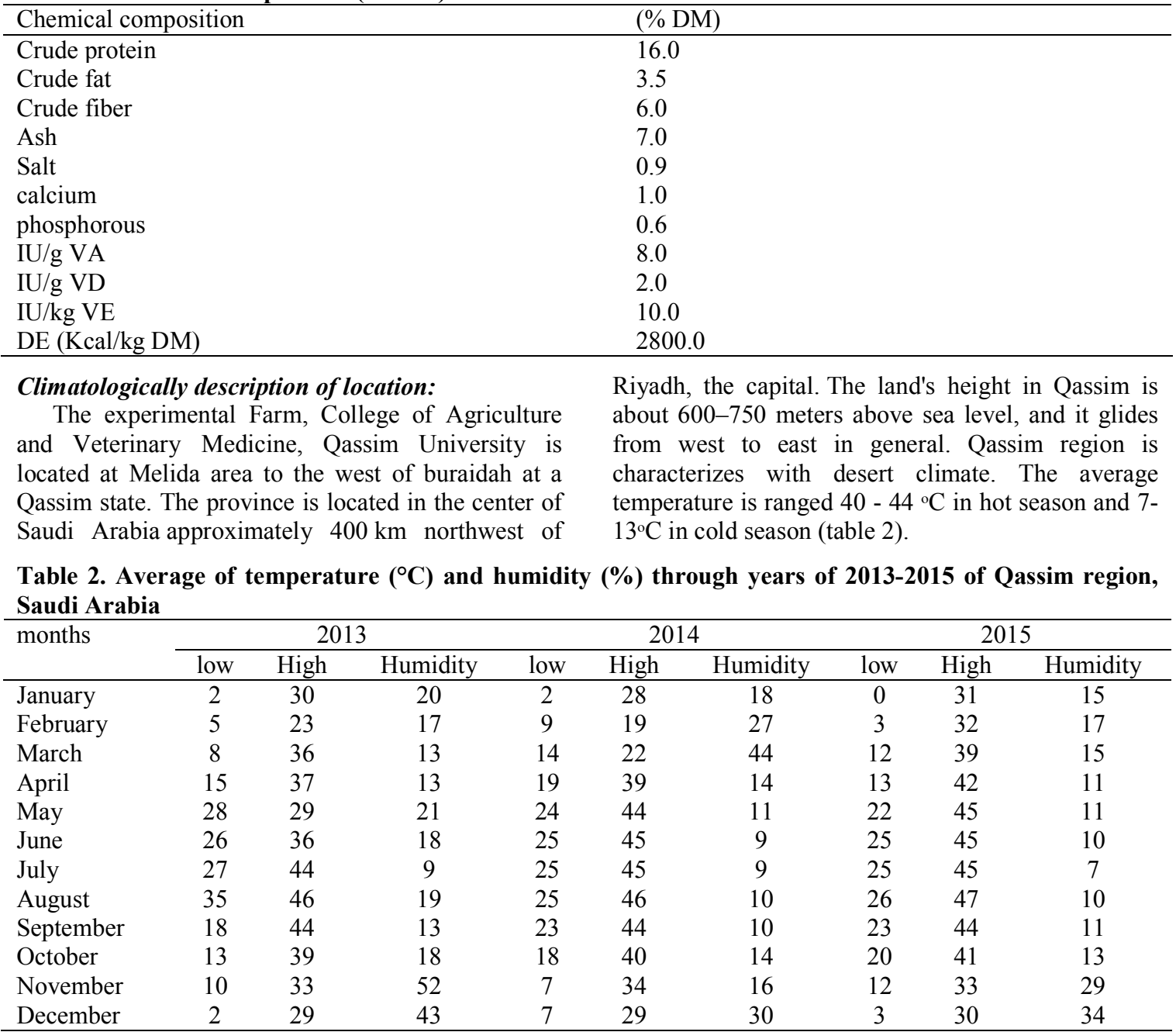

Source http://www.timeanddate.com/weather/saudia/buraidah/climate

Data Collecting :

Data were collected from thirty dairy cows Data were collected from thirty dairy cows through years 2013-2015 within two seasons; represented summer season (Jun-Sept) and represented winter season (Oct-Jan). Body weight at calving was measured using a weight tape which transform the girth circumference $(\mathrm{cm})$ to estimate weight $(\mathrm{kg})$. Immediately behind the front legs, over the heart is the spot. Tighten the tape too much and you under estimate the weight. Pull to lightly and you over estimate the weight. Body temperature was measured by electronic thermometer, which was inserted into the anus and then measure the body temperature. Pulsation rate was measured through coccygeal artery by pressure the artery for 1 minute. Respiration rate was determined by observing the movements chest. Body temperature, pulsation and respiratory were measured daily in the morning. Body activity was measured by using activity device pedometer (solar power pedometer, body sculpture company, China), which is fixed on neck collar. The measurement was taken twice per day at the time of milking. The body condition score was measured by visual observation and manual assessment to a scale of five-point, $1=$ extremely thin to $5=$ extremely fat (Heinrichs and Ishler, 2011).

The parameters studied represent physiological parameters, weight at calving, body activity (movement), total milk yield, daily milk yield, first estrus after calving, calving to conception interval (days open), number of services per conception, estrus rate and pregnancy rate.

\section{Statistical analysis:}

Data were analyzed using proc GLM procedure according to SAS (2000). The model included season of calving and body condition score as fixed effect, was as follows: Yijk $=\mu+\mathrm{Si}+\mathrm{B}_{\mathrm{j}}+(\mathrm{SB})_{\mathrm{ij}}+\mathrm{e}_{\mathrm{ijk}}$ where:

$\mathrm{Y}_{\mathrm{ijk}}=$ an observation taken on the $\mathrm{k}^{\text {th }}$ animal, $\mu=$ overall mean, $S_{j}=a$ fixed effect of the $i^{\text {th }}$ season 
( $\mathrm{i}=$ winter to summer), $\mathrm{B}_{\mathrm{j}}=\mathrm{a}$ fixed effect of body condition score, $(\mathrm{SB})_{\mathrm{ij}}=$ interaction between season and body condition score and $\mathrm{e}_{\mathrm{ij}}=$ Random error assumed to be independent by and normally distributed with mean $=0$ and variance $=\sigma^{2}$. Duncan multiple range test was conducted to determine differences among means, using 5\% significant level.

\section{RESULTS}

Results in Table 3 showed that the physiological parameters increased in hot season. The body temperature of cows was similar during cold and hot season while it was recorded the highest degree for cows with BCS 2 and there were smaller differences in the other BCS of 3 and 4 degrees. BCS had significant differences. Respiration rate significantly increased in hot season. The cows with BCS 2 degree showed the highest rate. The differences between BCS were significant $(\mathrm{P}<0.01)$. The same trend was observed for pulse rate where cows calved in hot season had highest rate. Pulse rate significantly decreased as the BCS degree increased.

The productive traits are summarized in Table 4 . Cows calved in hot season have lower body weights at calving, lower daily milk yield and lower amount of total milk than those calved in cold season. Cows calved in hot season showed higher movement than those in cold season. However season of calving had significant effect on all productive traits except body weight at calving. Increased $\mathrm{BCS}$ at calving resulted in heavier body weight. Cows with BCS grade 3 showed the highest movement and gave the heaviest amount of daily milk yield and total milk yield. In general BCS had significant effect on productive traits.

Table 5 summarizes the effect of season of calving and body condition score degrees on reproductive performance of Friesian cows. Lower reproductive traits were found for cows calved in hot season where they needed more numbers of services and showed longer days for first estrus after calving and longer days open. Regards to estrus rate and pregnancy rate were lower in cows calved in hot season. Highly significant effect of season was found for days to first estrus after calving, days open and pregnancy rate. Results in Table 5 indicated that cows with third degree BCS had the lowest days open and highest pregnancy rate. Equal rate of estrus was observed for body condition score 3 and 4 . Cows with grade 2 showed lowest number of services and lowest days to the 1st estrus after calving. BCS had highly significant effect on all reproductive traits studied except days to 1 st estrus after calving and days open.

Table 3. Effect of cold and hot season and body condition score (BCS) on physiological parameters of Friesian cattle

\begin{tabular}{lccc}
\hline & $\begin{array}{c}\text { Rectal temperature } \\
\left({ }^{\circ} \mathbf{C}\right)\end{array}$ & $\begin{array}{c}\text { Respiration rate } \\
\text { (count/minute) }\end{array}$ & $\begin{array}{c}\text { Pulse rate } \\
\text { (count/minute) }\end{array}$ \\
\hline Season & & & $56.2^{\mathrm{b}}$ \\
Cold & 38.5 & $21.6^{\mathrm{b}}$ & $73.8^{\mathrm{a}}$ \\
Hot & 38.8 & $46.2^{\mathrm{a}}$ & $68.3^{\mathrm{a}}$ \\
BCS & & & $65.3^{\mathrm{ab}}$ \\
2 & $38.9^{\mathrm{a}}$ & 34.8 & $61.4^{\mathrm{b}}$ \\
3 & $38.4^{\mathrm{b}}$ & 34.3 & 3.07 \\
4 & $38.5^{\mathrm{b}}$ & 32.6 & $* *$ \\
SEM & 0.09 & 4.1 & $*$ \\
Significance & $\mathrm{NS}$ & $* *$ & $* *$ \\
Season & $*$ & $\mathrm{NS}$ & \\
BCS & $\mathrm{NS}$ & $* *$ & \\
Season x BCS & \multicolumn{2}{c}{ NS not significant }
\end{tabular}

Table 4. Effect of cold and hot season and body condition score (BCS) on productive performance of Friesian cattle

\begin{tabular}{lllll}
\hline \multicolumn{2}{c}{ Body weight (kg) } & Movement (move) & Daily milk yield (kg) & total milk yield (kg) \\
\hline Season & & & & \\
Cold & 597.01 & $206.84^{\mathrm{b}}$ & $18.13^{\mathrm{a}}$ & $5077.62^{\mathrm{a}}$ \\
Hot & 559.54 & $277.04^{\mathrm{a}}$ & $16.80^{\mathrm{b}}$ & $4406.34^{\mathrm{b}}$ \\
BCS & & & \\
2 & & & \\
3 & $434.1^{\mathrm{b}}$ & $135.05^{\mathrm{b}}$ & $14.44^{\mathrm{b}}$ & $3996.46^{\mathrm{b}}$ \\
4 & $630.74^{\mathrm{a}}$ & $296.21^{\mathrm{a}}$ & $21.26^{\mathrm{a}}$ & $5798.80^{\mathrm{a}}$ \\
SEM & $670.0^{\mathrm{a}}$ & $294.56^{\mathrm{a}}$ & $16.70^{\mathrm{b}}$ & $4430.69^{\mathrm{b}}$ \\
Significance & $16 . .7$ & 32.1 & 0.37 & 447.35 \\
Season & $\mathrm{NS}$ & $* *$ & $*$ & $*$ \\
BCS & $*$ & $*$ & $* *$ \\
Season x BCS & $*$ & $* *$ & $*$ & $*$ \\
\hline SEM: standard error of the mean. ${ }^{\mathrm{a}, \mathrm{b}}-$ Values in column with different letters differ significantly , ${ }^{*}(\mathrm{P}<0.05),{ }^{*}(\mathrm{P}<0.01)$.
\end{tabular}


Table 5. Effect of cold and hot season and body condition score (BCS) on reproductive performance of Friesian cattle

\begin{tabular}{|c|c|c|c|c|c|}
\hline & $\begin{array}{l}\text { No of } \\
\text { services }\end{array}$ & $\begin{array}{l}\text { 1st estrus after } \\
\text { calving (day) }\end{array}$ & $\begin{array}{l}\text { Days open } \\
\text { (day) }\end{array}$ & Estrus rate $(\%)$ & $\begin{array}{l}\text { Pregnancy rate } \\
(\%)\end{array}$ \\
\hline \multicolumn{6}{|l|}{ Season } \\
\hline Cold & 2.2 & $73.07^{\mathrm{b}}$ & $89.14^{\mathrm{b}}$ & $95.24^{\mathrm{a}}$ & $72.86^{\mathrm{a}}$ \\
\hline Hot & 2.4 & $106.86^{\mathrm{a}}$ & $162.88^{\mathrm{a}}$ & $83.33^{\mathrm{b}}$ & $19.82^{b}$ \\
\hline \multicolumn{6}{|l|}{ BCS } \\
\hline 2 & $1.86^{\mathrm{b}}$ & $83.5^{\mathrm{b}}$ & $149.65^{\mathrm{a}}$ & $67.86^{\mathrm{b}}$ & $14.29^{b}$ \\
\hline 3 & $2.36^{\mathrm{a}}$ & $85.92^{\mathrm{b}}$ & $92.45^{\mathrm{b}}$ & $100.0^{\mathrm{a}}$ & $66.43^{\mathrm{a}}$ \\
\hline 4 & $2.68^{\mathrm{a}}$ & $100.49^{\mathrm{a}}$ & $135.94^{\mathrm{a}}$ & $100.0^{\mathrm{a}}$ & $58.30^{\mathrm{a}}$ \\
\hline SEM & 027 & 9.10 & 12.75 & 4.82 & 7.11 \\
\hline \multicolumn{6}{|l|}{ Significance } \\
\hline Season & NS & $* *$ & $* *$ & $*$ & $* *$ \\
\hline $\mathrm{BCS}$ & $*$ & $*$ & $*$ & $* *$ & $*$ \\
\hline Season $x$ BCS & $*$ & $* *$ & * & $* *$ & $* *$ \\
\hline
\end{tabular}

\section{DISCUSSION}

The present results showed that cows had an ability to survive under high ambient temperature. They increased the physiological parameters (rectal temperature, respiration rate and pulse rate) to increase cooling of their bodies and adjusted the high temperature. These results are in agreement with results of (Maurya et al., 2007; Bhan et al., 2012; Kumar et al., 2017 and Pandey et al., 2017). Rectal temperature is used as a good guide for thermal balance in dairy cows reared under hot environments (Rejeb et al., 2016 and Ghassemi Nejad et al., 2019). Many authors illustrated the increasing of physiological parameters to the neural signals to the hypothalamus as a reaction of skin receptors which resulted in increasing respiration rate (Haidary and Ahmed, 2004) while increasing blood flow to the surface of the skin resulted in an increase of pulse rate (Marai et al., 2007). Also, many studies pointed out that animals reared under hot temperature increased their respiratory rate for cooling body temperature (Indu \& Pareek, 2015; Ghosh et al., 2017 and Rashamol et al., 2018).

In this study, there is a clear reduction in productive and reproductive efficiency of cows during the hot season. The common situation that often occur in cattle during hot weather is losses body weight which leads low production and reproduction performance. The productivity of cow was greatly affected by a rise in environmental temperature where any increase in environmental temperature has a direct negative effect on milk production by reduce feed intake which is directly associated with negative energy balance, which largely responsible for the decline in milk synthesis (Wheelock et al., 2010 and Rejeb et al., 2016).

High air temperature led to reduction of cellular functions by direct alteration and impairment of various tissues or organs of the reproductive system (Das et al., 2016). Based upon these adverse effects of heat stress on follicular estradiol production and follicle dynamics, it is not surprising that heat stress reduces the length and intensity of estrus. In present study, estrus rate was significantly evident during cold season than hot season and the first estrus after calving was longer in hot season than cold season. This result is in agreement with Ghosh et al. (2017) who found that heat stress resulted in low function of cellular and reduce estrus rate. Perea et al. (2006) reported that cows during the summer showed half mounts per estrus. On a commercial dairy in Florida, undetected estrous events were estimated at 76 to 82 $\%$ during June through September compared to 44 to $65 \%$ during October through May (Thatcher and Collier, 1986). Heat stress reduces the length and intensity of estrus besides increases incidence of anestrous and silent heat in farm animals (Singh et al., 2013). The present results showed that season of calving had significant effect on most reproductive traits studied in favor of cold season. Similar trend was found by Dash et al., (2016) who reported that cows calved in summer season had the longest service period and had the lowest pregnancy rate. Multifactorial mechanisms involved in reducing fertility of dairy animals depending on the magnitude of heat stress. Heat stress reduces oocyte development by affecting its growth and maturation (Singh et al., 2013). Moreover, $80 \%$ of estrus may be unnoticeable during summer (Rutledge, 2001) which further reduces fertility. Plasma follicle-stimulating hormone (FSH) surge increases and inhibit concentrations decrease during heat stress leading to variation in follicular dynamics and depression of follicular dominance that could be associated with low fertility of cattle during the summer and autumn (Roth et al., 2000). Recently, heat stress decreases fertility by diminishing quality of oocytes and embryos through direct and indirect effects (Lacerda and Loureiro, 2015) where the oocytes of cows lose their competence for fertilization (Gendelman and Roth, 2012).

Regards to the effect of body condition score (BCS) on productive and reproductive performance, the present results showed that BCS had significant influence on both performance in favor of cows with 
3 and 4 BCS. These results are in agreement with those reported by Berry et al. (2007), Roche et al. (2007) and Alphonsus et al. (2014) who explained the high milk yield or high reproductive traits with increased BCS at calving to the increase in DMI and to good health of udder.

\section{CONCLUSION}

Results from the present study throw a light on the ability of Friesian cows to withstand the hot climate. Body activity, milk yield and reproductive traits are affected by season of calving especially hot season. BCS at calving is considered an important factor for checking the economic efficiency of cows under tropical and subtropical areas. The results indicated that BCS between 3-4 is required to realize high productive and reproductive performance of cows under high ambient temperature.

\section{Competing Interests:}

The authors declare that they have no conflict of interests.

\section{REFERENCE}

Alphonsus, C., Akpa, G.N., Barje, P.P., Ayigun, E.A., Zanna, M., Opoola, E. and Abdulahi, I. 2014. Effect of post-partum body condition score on milk yield and composition of friesian $\mathrm{x}$ bunaji dairy cows . Animal Research International 11(3): $2048-2056$.

Badinga, L., Thatcher, W.W., Diaz, T., Drost, M. and Wolfenson, D. 1993. Effect of environmental heat stress on follicular development and steroidogenesis in lactating Holstein cows. Theriogenology 39 797-810.

Berry, D.P., Buckley, F. and Dillon, P. 2007. Body condition score and live-weight effects on milk production in Irish Holstein-Friesian dairy cows. Animal 1 (9): 1351-1359. doi: 10.1017/S1751731107000419.

Bhan, C., Singh, S.V., Hooda, O.K., Upadayay, R.C., Beenam and Vaidya, M. 2012. Influence of temperature variability on physiological, hematological and biochemical profile of growing and adult Sahiwal cattle. J. Environ. Res. Dev. 7: 986-994.

Das, R., Sailo, L., Verma, N., Bharti, P., Imtiwati, S.J. and Kumar, R 2016 Impact of heat stress on health and performance of dairy animals: A review, Veterinary World, 9(3): 260-268.

Dash, S., Chakravarty, A.K., Singh, A., Upadhyay, A., Singh, M. and Yousuf, S. 2016. Effect of heat stress on reproductive erformances of dairy cattle and buffaloes: A review. Vet. World, 9: 235-244.

Gendelman, M. and Roth, Z. 2012. Seasonal effect on germinal vesicle-stage bovine oocytes is further expressed by alterations in transcript levels in the developing embryos associated with reduced developmental competence. Biol. Reprod., 86 (1): 1-9.
Ghassemi Nejad, J., Kim, B.W., Lee, B.H. and Sung, K.I. 2019. Body temperature responses and hair cortisol levels in dairy Holstein cows fed highand low-forage diet and under water deprivation during thermal-humidity exposure. Ann. Anim. Sci., 19 (1): 113-125.

Ghosh, C.P., Kesh, S.S., Tudu, N.K. and Datta, S. 2017. Heat stress in dairy animals - its impact and remedies: A Review. Int. J. Pure App. Biosci. 5 (1): 953-965. http://dx.doi.org/10.18782/23207051.2577 .

Haidary, A.1. and Ahmed, A. 2004. Physiological responses of Naimey sheep to heat stress challenge under semi-arid environments. Int. J. Agric. Biol. 2: 307-309.

Heinrichs, J. and Ishler, V.A. 2011. Body Condition Scoring as a Tool for Dairy Herd Management. Department of Dairy and Animal Science, the Pennsylvania State University

Indu, S. and Pareek, A. 2015. A Review: Growth and Physiological Adaptability of Sheep to Heat Stress under Semi-Arid Environment. International Journal of Emerging Trends in Science and Technology. doi 10.18535/ijetst/v2i9.09.

Kumar, J., Kumar, M., Madan, R.K., Singh, Y., Yadav, B. and Anand, M. 2017. Effect of season on physiological parameters and production profile of Hariana and Sahiwal cattle. Haryana Vet. 56 (1), 69-71.

Lacerda, T.F. and Loureiro, B. 2015. Selecting thermotolerant animals as a strategy to improve fertility in Holstein cows. Glob. J. Anim. Sci. Res., 3(1): 119-127.

Marai, I.F.M., El-Darawany, A.A., Fadiel, A. and Abdel Hafez, M.A.M. 2007. Physiological traits as affected by heat stress in sheep a review. Small Ruminant Res. 71: 1-12.

Maurya, V.P., Naqvi, S.M.K., Joshi, A. and Mittal, J.P. (2007). Effect of high temperature stress on physiological responses of Malpura Sheep. Indian J. Anim. Sci. 77: 1244-1247.

Pandey, P., Hooda, O.K. and Kumar, S. 2017. Impact of heat stress and hypercapnia on physiological, hematological, and behavioral profile of Tharparkar and Karan Fries heifers. Veterinary World, 10(9): 1149-1155.

Perea, F.G., Soto, E.B., Hern'andez, H.F., Gonz'alez, D.V. Palomares, R.N., De Ondiz, A.S. and Gonz'alez, C.S. 2006. Monthly variation of fertility and oestrus frequency in crossbred dualpurpose cows in three agroecological areas of the South American tropics. Trop Anim Health Prod., 38:353-363. Doi 10.1007/s11250-006-4316-5.

Rashamol, V.P., Sejian, V., Bagath, M., Krishnan, G., Archana, P.R. and Bhatta, R. 2018. Physiological adaptability of livestock to heat Stress: an updated review. J Anim Behav Biometeorol 6: 62-71. http://dx.doi.org/10.26667/23181265jabb.v6n3p62-71. 
Rejeb, M., Sadraoui, R., Najar, T. and, Ben M'rad, M. (2016). A complex interrelationship between rectal temperature and dairy cows' performance under heat stress conditions. Open J. Anim. Sci., 6: 24-30.

Rensis, F.D. and Scaramuzzi, R.J, 2003. Heat stress and seasonal effects on reproduction in the dairy cow-a review. Theriogenology 60 : 1139-1151. doi:10.1016/S0093-691X(03)00126-2.

Rensis, F.D., Marconi, P., Capelli, T., Gatti, F., Facciolongo, F., Franzini, S., et al. 2002. Fertility in postpartum dairy cows in winter or summer following estrous synchronization and fixed time A.I. after the induction of an LH surge with Gonadotropin releasing hormone $(\mathrm{GnRH})$ or human chorionic gonadotropin (hCG). Theriogenology 2002;58:1675-87.

Roche, J.R., Lee, J.M., Macdonald, K.A. and Berry, D.P. 2007. Relationships between body condition score, body weight and milk production variables in pasture-based dairy cows. Journal of Dairy Science, 90(8):3802-3815. doi: 10.3168/jds. 2006-740.

Roth, Z., Meidan, R., Braw-Tal, R. and Wolfenson, D. 2000 Immediate and delayed effects of heat stress on follicular development and its association with plasma FSH and inhibin concentration in cows. J. Reprod. Infertil., 120(1): 83-90.
Roth, Z., Meidan, R., Braw-Tal, R. and Wolfenson, D. 2000. Immediate and delayed effect of heat stress on follicular development and its association with plasma FSH and inhibin concentration in cows. J Reprod Fertil120:83-90.

Rutledge, J.J. 2001. Use of embryo transfer and IVF to bypass effects of heat stress. Theriogenology, 55(1): 105-111.

SAS, 2000. SAS user guide: Statistics. Version 8 edition. SAS Institute Inc., Cary, NC.

Singh, M., Chaudhari, B.K., Singh, J.K., Singh, A.K. and Maurya, P.K. 2013 Effects of thermal load on buffalo reproductive performance during summer season. J. Biol. Sci., 1(1): 1-8.

Thatcher, W.W. and Collier, R.J. 1986. Effects of climate on reproduction in : current therapy in theriogenology. D. Morrow ed., Philadelphia: Saunders. Pp. 301-310

Usman, T., Qureshi, M.S., Yu, Y. and Wang, Y. 2013. Influence of various environmental factors on dairy production and adaptability of Holstein cattle maintained under tropical and subtropical conditions. Advances in Environmental Biology, 7(2): 366-372.

Wheelock, J.B., Rhoads, R.P., VanBaale, M.J., Sanders, S.R. and Baumgard, L.H. 2010. Effects of heat stress on energetic metabolism in lactating Holstein cows. J. Dairy Sci. 93 (2) :644-655 doi: $10.3168 /$ jds.2009-2295

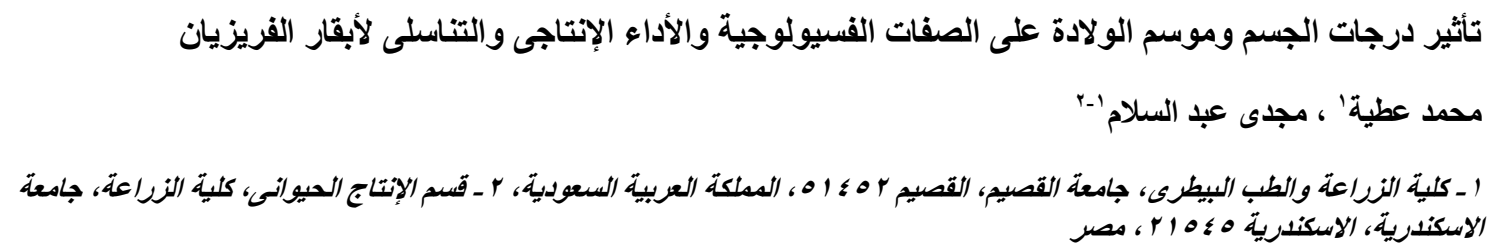

اثرت حالة جسم الأبقار المرباة في المناطق الاستو ائية وشبه الاستوائية على الصفات الإنتاجية و التناسلية. وتعتبر الكفاءة التناسلية عاملاً هامًا

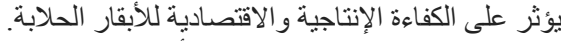

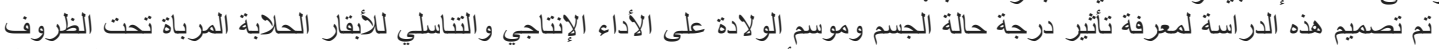



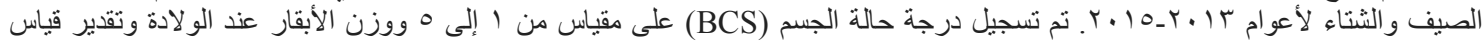

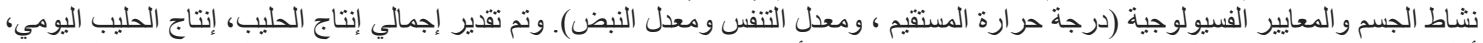



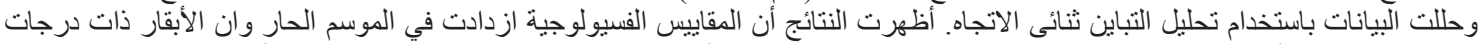

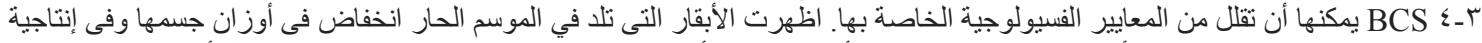



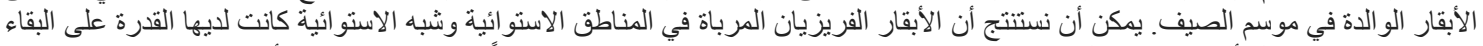

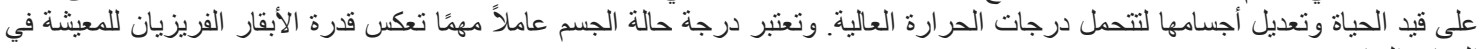

